\title{
ANALYSIS ON THE APPLICATION AND BENEFIT OF FIELD TRIP TO KEBUN RAYA BOGOR ON ECOLOGY SUBJECT IN BIOLOGY EDUCATION STUDY PROGRAM ACADEMIC YEAR 2016/2017
}

\author{
Indri Yani ${ }^{1)}$ \\ 1) Universitas Pakuan, Bogor, Indonesia \\ Corresponding Author: indri@unpak.ac.id
}

\begin{abstract}
The aim of this research is to find out the application and benefit of field trip to Kebun Raya Bogor on Ecology subject in Biology Education Program, FKIP Unpak Bogor.This research is conducted at Kebun Raya Bogor on January during academic year of 2017. Population of this research is students of fourth semester Biology Education Study Program, FKIP Unpak Bogor who attend field trip on ecology subject.Descriptive method is used in this research to describe and analyze the advantages and the application of field trip to Kebun Raya Bogor on ecology subject. Instrument used in this research is questionnaire. Based on the data analysis and the research result it can be said that the application of field trip on ecology subject shows good impact. The successfulness of this field trip is because all students involve in the activity and follow the procedure as it was written on the manual. The benefit of field trip is to prove theory that students learn in the classroom.
\end{abstract}

Keywords: field trip, ecology subject.

\section{INTRODUCTION}

Ecology is a subject that discusses the interaction (reciprocal relationship) between organism and its environment, which is the interaction that decides the spreading and abundance of organism. At its very core ecology discuss about ecosystem.

As the time pass, ecology has become important branch of knowledge, because it discusses the change in ecosystem. Nowadays, as the human population increases life's infrastructure is affected such as the expansion of housing complex, high ways, industry, and deforestation for other purposes, many products that polluted the environment also global warming issue and natural disasters. In turn ecology can improve understanding and awareness to maintain and preserve nature.

in order to develop students' understanding and awareness on balance and diversity of natural ecosystem, wildlife diversity and the ability to observe animals and vegetation analysis, field trip is necessary to be applied. This activity gives direct experience in nature by exploring and observing ecosystem, wildlife diversity and field data analysis for ecology discussion, as well as about structure and function of ecosystem.

Nature is complete and excellent laboratory. Therefore, the knowledge on diversity distribution and plants and animals abundance, as well as its interaction with the environment will be more meaningful if accompanied by direct field observation. In that case, field trip is a way for students to expand their cognitive, affective and psychomotor aspects. Through field trip students can verified many theories in ecology. Beside that, by directly involved in the field students can observe natural habitat of all species of plants and animals. Field trip is an outdoor activity. The reason behind this field trip is to apply theory learnt in the classroom into the field. The benefits of field trip are to apply or observe factually theories learnt in the classroom.

It is to be understood that the advantages of field trip has to be in accordance to the procedure and equipment needed to conduct the application of it in order to fulfill the purpose itself. Furthermore, field trip also giving factual knowledge for students who attend it compared to students who are not.

Based on the explanation above the writer conduct a research entitles "An analysis of field trip and its advantages in Kebun Raya Bogor on Ecology subject." The problems are formulated as follows: 1) do students get many benefits from the application of field trip to Kebun Raya Bogor on ecology subject? and 2) how is the field trip conducted at Kebun Raya Bogor on Ecology subject?

According to Odum [1] Ecology is known as the study of reciprocal relationships between living things and their environment. Living things in the case of agriculture are plants, while the environment can be in the form of air, soil, nutrients, etc. Whereas according to Begon [2] some biologists in the 18th and 19th centuries have also studied fields which were later included in the ecological scope. 
According to Zoer'aeni [3], people who study ecology actually question various things, including: 1 . How nature works; 2. How do species move in their habitat; 3 . What is needed from the habitat of its habitat to sustain life; 4. How life fulfills material and energy needs; 5 . How is the interaction between species in the environment; 6 . How are individuals in the species being and working as populations.

According to Roestiyah, [4] field trip is a method of teaching which done by taking students to some place or a certain object outside the school to observe or investigate something such as observation to shoe factory, car garage, convenient store, farm, garden, playground and so on. Sharing the same idea Nursid, 1984 stated that field trip is a study tour to a certain object outside the campus, under lecturer supervision to achieve a certain instructional goal. According to Roestiyah [4] the aim of field trip is for the students to be able to (1) get direct experience from object that they see, (2) cooperate with others, able to discuss and share information so that they can solve problems during learning process, (3) listen, investigate and examine so that they can make conclusion and at the same time they can learn several lectures and, (4) to have better understanding and appreciation of the environment.

According to Syaiful Bahri [5] the field lecture method or field trip has several advantages including: a. field trip has modern teaching principles that utilize the real environment in teaching. b. Making what is learned on campus more relevant to the reality and needs of the community. c. This kind of teaching can further stimulate student creativity. d. Information as a broader and more actual subject matter.

In daily life, especially in country side we have seen farmers cultivating their land, planting seed, watering the land; fertilize it and other farming activities. This activity has been done for centuries. Basically they knew that there is an interaction between plants and the land, plants and the water, plants and humus and so on. The activity of the farmer is basically an application of ecology. It means that the ecology has been applied long before the term itself was introduced by the expert. Today's farming has applied many natural principal to support good ecology processes. Back in the day, farming is still very simple but today is already applying ecology principals, for example the use of many fertilizers. The farmers basically knew that in cattle's dung, dead leaves contains humus needed by the plants, therefore it helps ecology process especially humus cycle.

\section{RESEARCH METHODS}

This research is aimed at finding out the application and advantages of field trip to Kebun Raya Bogor on ecology subject. Descriptive method is used in this research. The sample used in this research is students of the fourth semester of Biology Education
Study Program who attended field trip in ecology subject.

Data collection of this research is observation on the application of field trip process, while for the analysis is focused on the advantages and the application of field trip in Kebun Raya Bogor. Instrument used in this research is questionnaire which will be answered by the participants. The questionnaire consists of several written questions which will be used to gain information from participants about the advantages and the application of field trip..

\section{RESULTS AND DISCUSSION}

After 75 students of Biology Education Study Program academic year 2014 answered the questionnaire, score for every subject is calculated and analyzed. The result is shown in the table below:

Based on each items most answers fall under good criteria. Each question is discussed in detail below:

1. The application of field trip is on $33,33 \%$ with good criteria. The application of field trip will be smooth when it is conducted according to the steps written in the theory by Syaiful Sagala [6] where there are several steps in conducting field trip: (1) Set the intended competence for students to achieve; (2) Planning the goals; (3) Formulating the activity; (4) Conducting activity (5) Assessing the activity; and (6) Reporting the result. Before conducting field trip students must be given instruction about the field trip.

2. The advantage of field trip is $42,67 \%$ under good criteria. Field trip gives advantage in accordance with the goal of field trip stated by Roestiyah [4] which is that students can (1) acquire direct experience from object that they see, (2) capable in working with other people, able to discuss and share so that they can solve their own problem during teaching learning process. (3) listen, investigate and try what have been encountered which in turn can help them to make a conclusion, and at the same time they can learn several lectures and (4) gives better understanding and appreciation on the environment, as supported by Orion \& Hofstein (1991a) field trip serves as (1) teaching aid; (2) encourage individual learner, (3) contain social aspect, (4) adventure aspect, and (5) environmental aspect.

3. The role of lecturer in field trip is $46,67 \%$ under good criteria. The application of field trip will be smooth when lecturer and students understand their role. It is emphasize by Syaiful through his statement in which the application of field trip will be optimum if lecturer and students have certain skill such as: lecturers' skill are: (1) can set the place or suitable objek wisata with the learning goal; (2) plan and prepare students manual in conducting field trip; (3) prepare the necessary equipment and tools; (4) supervise and control students activity during field 
trip; and (5) asses the result of field trip. On the hand students' skills are: (1) understand and apply the manual given by lecturer; (2) learning individually and in groups; (3) use suitable equipment and tools; and (4) compose report result of the field trip. field trip in Biology Education Study Program on Ecology subject shows good result, the successfulness of field trip is because all students conduct the field trip in accordance to the procedure written in the manual and instruction given by the lecturer; and 2) the benefit of

Table 1. Result Answered The Questionnaire

\begin{tabular}{|c|l|c|c|}
\hline No & \multicolumn{1}{|c|}{ Question item } & Criteria & Percentage \\
\hline 1 & How do you think about field trip & Good & $33,33 \%$ \\
\hline 2 & Do the field trip give benefit either for individual or groups & Good & $42,67 \%$ \\
\hline 3 & What do you think about the role of the lecturer during field trip & Good & $46,67 \%$ \\
\hline 4 & $\begin{array}{l}\text { What do you think about the technique and equipment used in field } \\
\text { trip }\end{array}$ & Good & $37,33 \%$ \\
\hline 5 & In your opinion what about the time allocation used in the field trip & Good & $36 \%$ \\
\hline 6 & What do you think about the application of field trip & Fair & $38,67 \%$ \\
\hline
\end{tabular}

4. Technique and equipment in field trip is $37,33 \%$ under good criteria. In the field trip on ecology subject, analyzing birds' population two techniques are used they are IPA method and transect method. As for the equipment students have prepare ropes, binocular, bird identification manual and camera. Technique and equipment used in field trip is considered good. This is supported by Syaiful's statement which said the application of field trip will be optimum when lecturer prepares equipment and tools needed and students can use them.

5. Time allocation for field trip is at $36 \%$ under good criteria. Field trip is conducted based on planned specific time allocation. Because the material is about analysis of birds' population therefore the field trip is done in the morning. Time accuracy both for students and lecturer in field trip help the process of writing the report.

6. students' opinion on field trip is $38,67 \%$ under good criteria because field trip both have plus and minus. It can be concluded that field trip method has some advantages, such as: (1) Students can observe various reality from the place they visit; (2) Students can enjoy new experiences; (3) Students can get direct information from their observation; and (4) Students can learn one material integrally and coherence. On the other hand the disadvantages from field trip are: (1) the cost for field trip is quite expensive; (2) sometimes it can be difficult to condition the students; (3) in many cases learning goal is not proportionally conveyed as the recreational is prioritized; and (4) it takes much longer preparation in order for the field trip to have run optimum..

\section{CONCLUSION}

Based on the result of the research and data analysis it can be concluded that: 1) the application of field trip is to prove theory that students learnt in the classroom

\section{REFERENCES}

[1] Odum, Eugene P. 1996. Dasar-Dasar Ekologi. Yogyakarta: Gajah Mada University Press

[2] Begon, M., J.L. Harper \& C.R. Townsend. 1986. Ecology. Individuals, Populations and Communities. Blackwell Sci. Pub. Oxford. Hamilton, L.S. and P.N. King. (1992). Daerah aliran sungai hutan tropika. Penerjemah: Krisnawati Suryanata. Gadjah Mada University Press. Yogyakarta.

[3] Irwan, Zoer'aini Djamal. 2007. Prinsip-prinsip Ekologi, Ekosistem, Lingkungan dan Pelestariannya. Jakarta: Bumi Aksara

[4] Roestiyah. Dkk. 2001. Strategi Belajar Mengajar. Jakarta: Rineka Cipta

[5] Djamrah, Syaiful Bahri. 2006. Strategi Belajar Mengajar. Jakarta: Rineka Cipta

[6] Sagala, Syaiful. 2006. Konsep dan Makna Pembelajaran. Bandung: Alfabet 